\title{
Contributions to a Bryoflora of the United Arab Emirates (UAE).
}

\author{
Hanaa M. Shabbara \\ and \\ Wagieh El-Saadawi \\ Botany Department, Faculty of Science, \\ Ain Shams University.Cairo-Egypt. \\ E- mail: elsaadawy@link.com.eg
}

Shabbara H.M. and El-Saadawi W. 1999. Contributions to a Bryoflora of the United Arab Emirates (UAE). Taeckholmia 19 (2):183-192.

Twenty-four out of 26 mosses, recently collected from the United Arab Emirates (UAE), are new records for the country and the total number is raised to 27 entities. Six of these mosses and Riccia subbifurca Warnst. ex Croz. are new records to the whole Arabian Peninsula. Upward-growing peculiar aerial rhizoids are recorded in six of the mosses. Reference to sporulation, sexual and asexual reproductive structures are made.

Key words: aerial rhizoids, bryophytes, United Arab Emirates.

\section{Introduction}

It was long thought that the Arabian Peninsula is very poor in bryophytes. The report of only two mosses from Yemen (Forsskål, 1775) and a single moss from Oman (Thériot et al. 1934) seems to have put more emphasis on this thought rather than eliminate it. Detailed intensive studies on the bryoflora of different countries of the Arabian Peninsula showed, however, that it is not that poor in mosses.

In a series of papers, El-Saadawi (1976, 1978, 1979a-b) enumerated the moss species encountered in Kuwait (Fig.1). He described niches where they grow in desert wadis, gave comments on adaptation, environment and drought resistance shown by some of them and reported for the first time on "peculiar aerial rhizoids" developed by four of these desert mosses (1979b). The report on remarkable persisting structures and drastic changes in the diversity of this desert bryoflora brought about by successive years of drought came in El-Saadawi \& Zanaty (1990) and Halwagy \& El-Saadawi (1992). Studies on Kuwaiti mosses were even extended to phytochemistry (Al-Hasan et al., 1989)

While trying to interpret the origin of the isolated desert bryoflora of Kuwait, ElSaadawi (1976) pointed out that the distribution of mosses throughout the world is required and that nothing is known of the moss flora of the Saudi Arabia. Frey \& Kürschner (1982), started working on the bryoflora of the Arabian Peninsula especially Saudi Arabia. Results of their extensive voluminous work (Jointly with other participants in some cases) have been published in a long series of papers (cf Kürschner, 1997) under a main title of "studies in Arabian bryophytes".

In addition to the above mentioned comprehensive works on Kuwait and Saudi Arabia, other mosses were reported from Yemen (Hepper, 1977; Townsend, 1979;

Received 16 May 1999. Revision accepted 28 November 1999. 
Delgadillo, 1982; Ochi \& Kürschner, 1988; Whitehouse \& Crundwell, 1992; Al-Gifri\& Kürschner, 1996; Kürschner, 1996a); from Yemen and Oman (Bruggeman-Nannenga, 1987; Frey \& Kürschner, 1991); from Oman (Whitehouse \& Crundwell, 1991; Kürschner, 1996b; Arts, 1998) and from The United Arab Emirates (Frey \& Kürschner, 1988). Accordingly, more than 150 moss taxa are, at present recorded from the Arabian Peninsula, with the largest number (110 taxa) from Saudi Arabia and the smallest ( 3 taxa) from U.A.E.

Although Socotra (Fig.1) is a Yemeni territory, yet we did not include its bryoflora with a total of 25 taxa reported by Schweinfurth (1884), Mitten (1888), Müller (1901), Balfour (1903), Townsend (1969), Long (1987), Frey and Kürschner (1988) and Al-Gifri et al. (1995). This island and its flora has closer affinities to the African continent. Bryofloristically it belongs to Af2 (see also Hodgetts et al., 1999).

The geomorphology, topography and climate of the UAE (especially the mountains of the northeast), all clearly suggest that plenty more than the 3 recorded mosses would be found there, if a careful survey was undertaken. This makes the aim of the present paper.

\section{Collecting sites}

UAE is a small country occupying only $c a .83600 \mathrm{Km}^{2}$ of the vast area of the Arabian Peninsula (Fig.1). It is bounded by Saudi Arabia, Oman, Gulf of Oman, Oman (again), Arabian Gulf, and Qatar (Figs.1\&2). It is mainly a desert lowland which ranges from 100 to $500 \mathrm{~m}$ a.s.l., with a limited mountainous area in the northeast which is $1000-2000 \mathrm{~m}$ (or more) a.s.l.

The average annual temperature is $17^{\circ}-37^{\circ} \mathrm{c}$. The coldest month is January and the hottest is August. Rain usually falls between November and May. The annual rainfall is $c a .50 \mathrm{~mm}$ or less in the desert lowland and ranges from 100 to $250 \mathrm{~mm}$ in the mountainous area. The rainfall is sporadic and fluctuates sharply in time and space; half the amount of annual rain may fall during one rainy storm. This is followed by sudden powerful torrents that rush through runnels and drain mainly to the east in the Gulf of Oman, or less frequently to the west in the desert plains. Porosity of rocks is low and water is held for some time under or between rocks, and in rock crevices to form suitable niches for the growth of mosses, annual flowering plants, numerous lichens, .....etc. (Figs. $3 \& 4)$.

Mosses and one liverwort were collected (by the second author) in January and February 1998 from 8 mountainous sites (Table 1\&Fig. 2), at elevations between 600- 800 m a.s.l.

\section{Details of these sites are as follows:}

Site 1: At rock bases of dry runnels, Khour-fakan, Sharja Emirate, UAE, 29.1.1998.

Site 2: On mud between inclined rocks; at bases of large boulders, a few kilometers from Fujayrah city, Fujayrah Emirate, UAE, 3.2.1998.

Site 3: Road Mark Km 4, along Fujayrah-Sharja road, among rocks facing sun almost all day, on the right side of the road, 5.2.1998.

Site 4: Road Mark Km 10, along Fujayrah-Sharja road, among rocks in runnels, on the right side of the road, 5.2.1998. 
Site 5: Road Mark Km 12, along Fujayrah-Sharja road, on mud among rocks with many runnels converge, in shade, on the left side of the road, 5.2.1998.

Site 6: Road Mark Km 25, along Fujayrah-Sharja road, among rocks of runnels, in shade in afternoons, on the left side of the road 6, 13.2.1998.

Site 7: Road Mark Km 39, along Fujayrah-Sharja road, at rock bases of dry runnels, on the right side of the road, 3.2.1998.

Site 8: Road Mark Km 40, along Fujayrah-Sharja road, on mud between rocks, on the right side of the road, 3.2.1998.

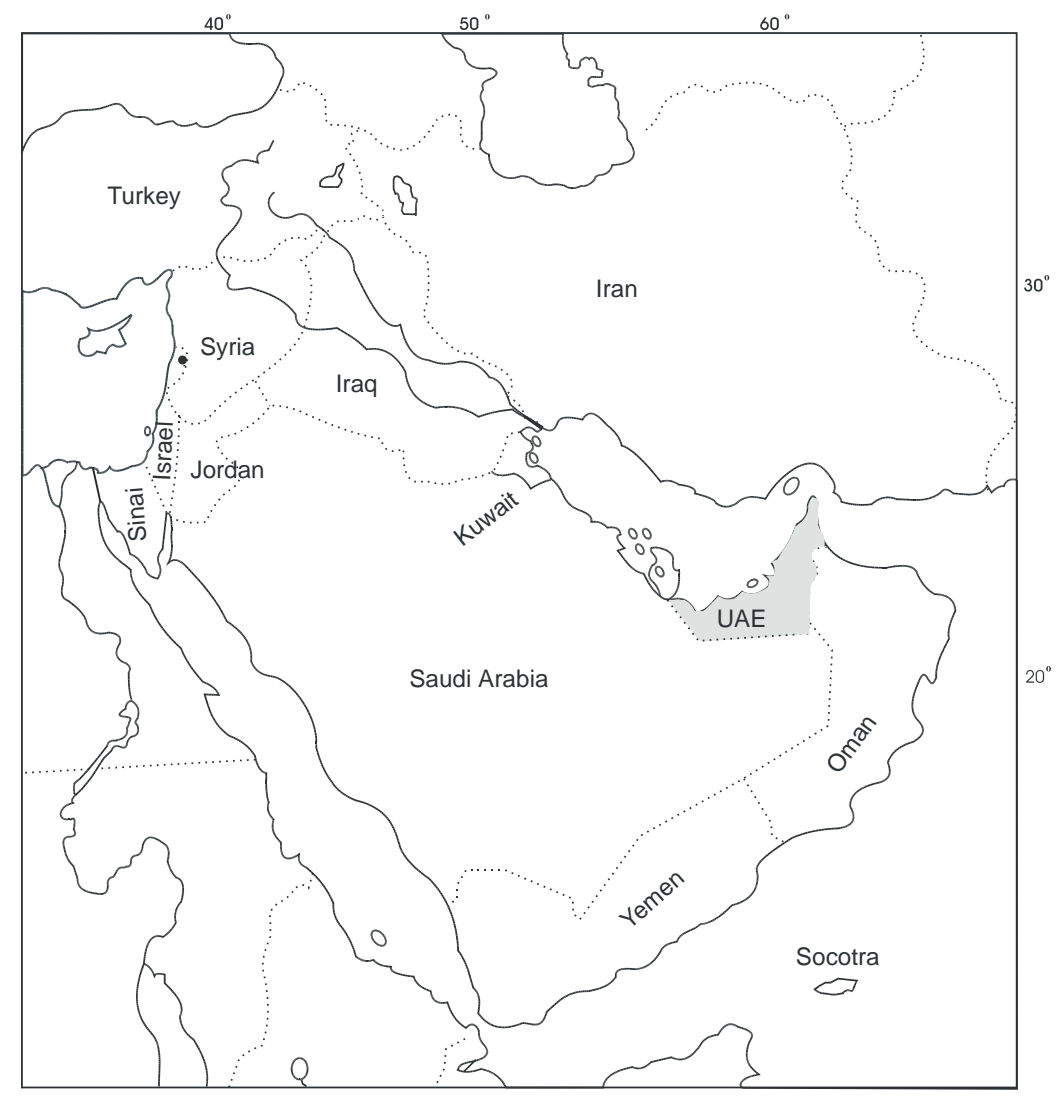

Fig. 1 Location of the United Arab Emirates (UAE) 


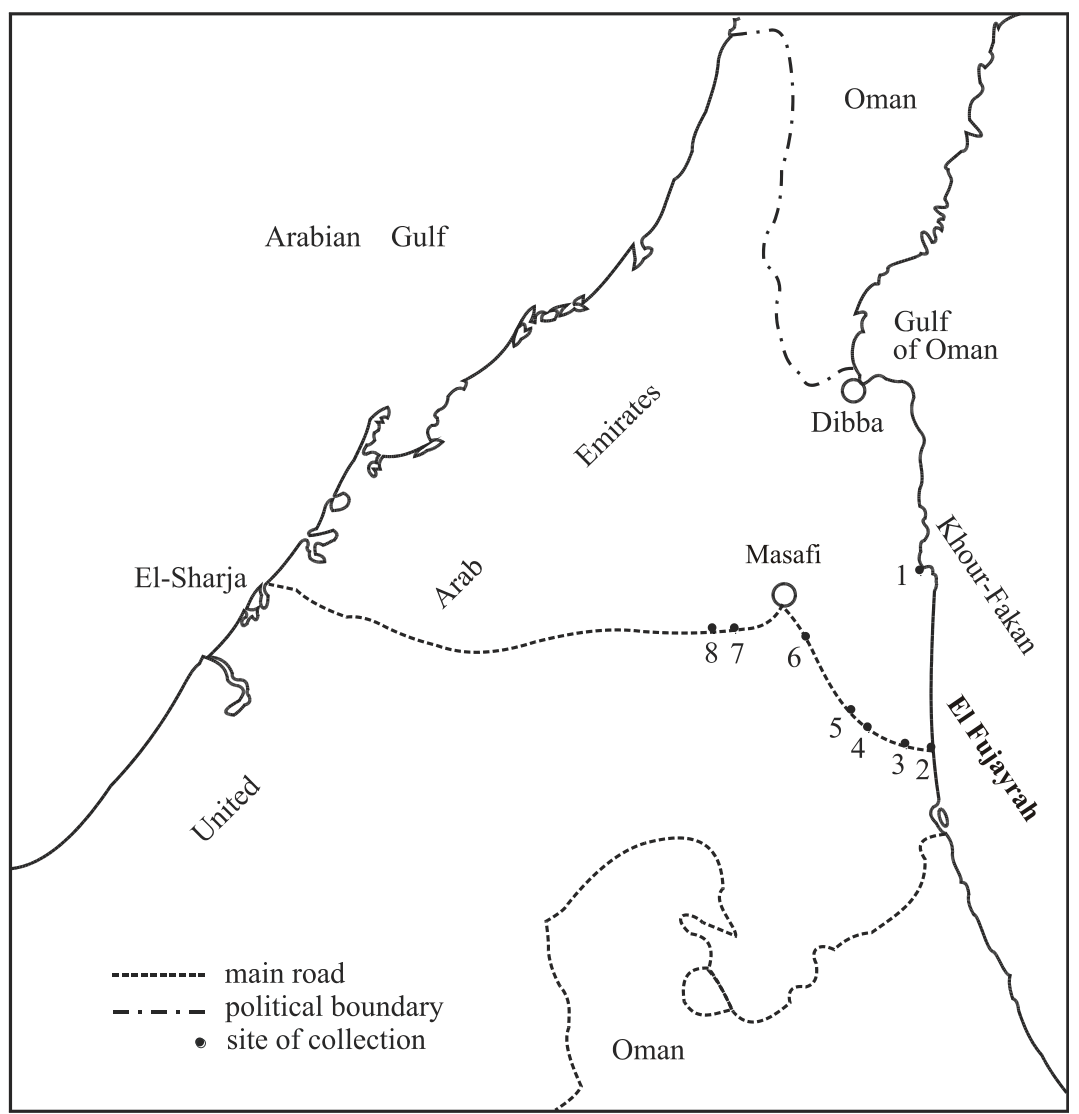

Fig. 2. Map of part of UAE showing locations of the eight sites of collection

\section{Observations and results}

Investigation of the collected samples (all kept at Ain Shams University Herbarium CAIA) proved that they include Riccia subbifurca Warnst. ex Croz. (a hepatic, site 4) and 26 mosses. Names of the mosses, other details as: distribution of each moss in the sites of collection, number of samples collected from each site, presence of sporophytes, sex organs, gemmae and aerial rhizoids are given in Table 1. 


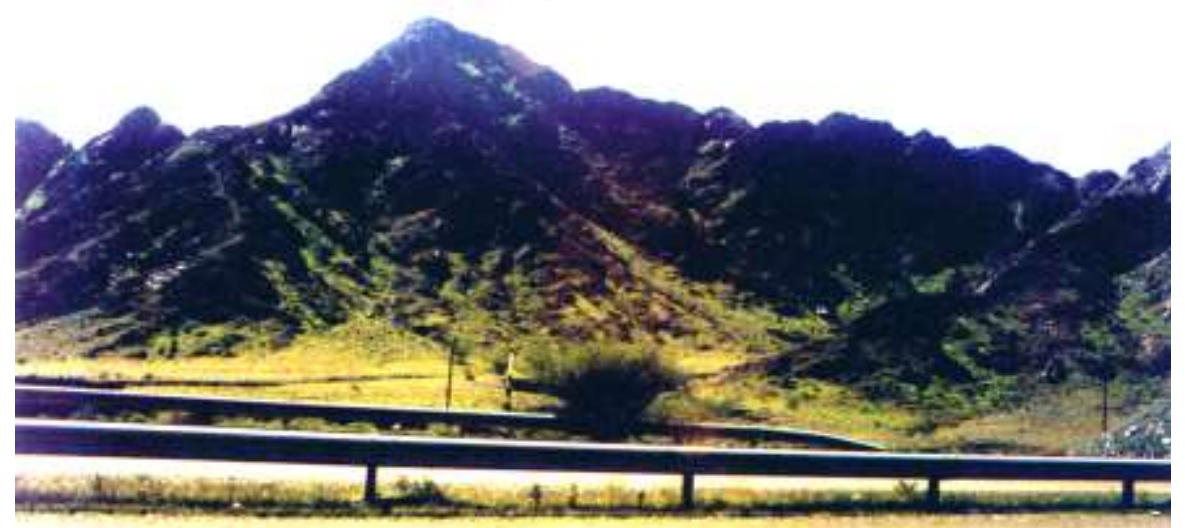

Fig. 3: Vegetation growing in runnels and slopes of one of the mountains located along Fujayrah-Sharja main road, 3.2. 1998

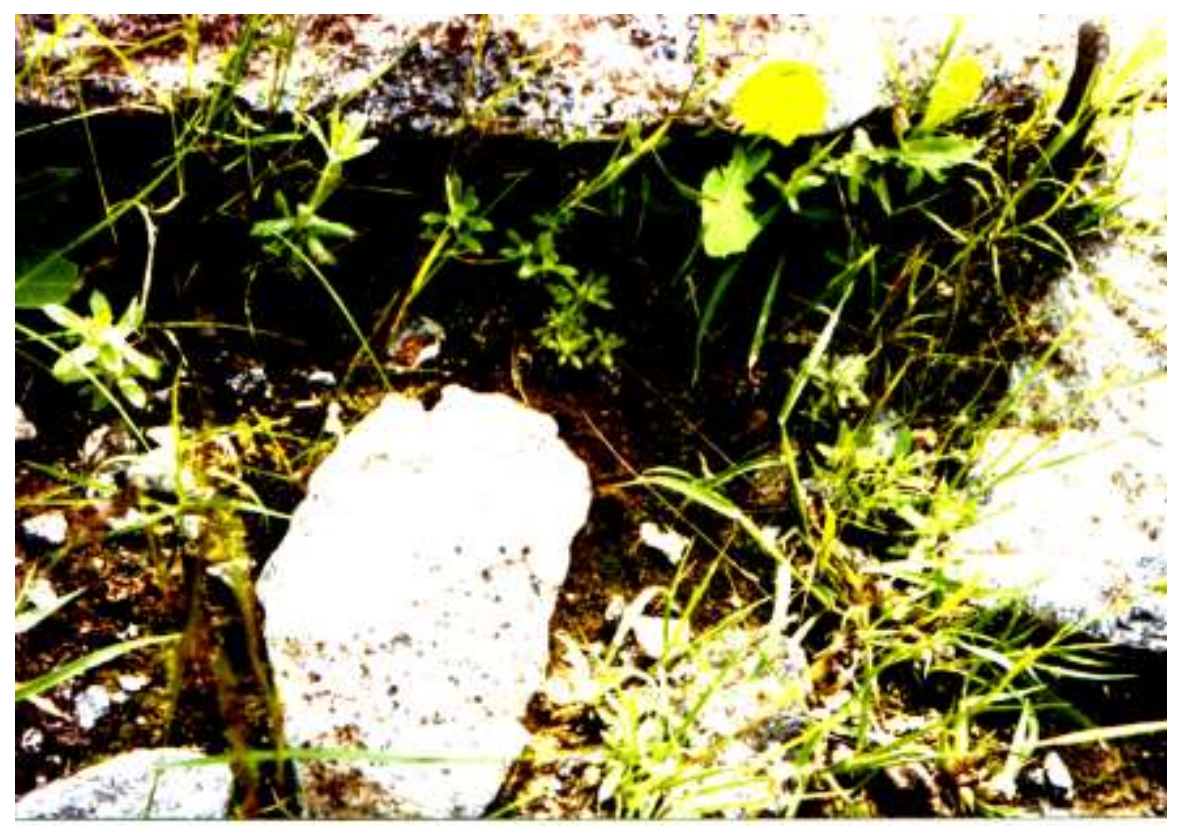

Fig. 3: Entosthodon attenuatus (with green unrip capsules) growing among rocks with herbaceous flowering plants, site 6, 6. 2. 1998. 
H.M. Shabbara and W. El-Saadawi

Table1: Data of the recorded taxa: sites of collection, no. of samples; presence of sporophytes (f), archegonia (c), antheridia (t), axillary gemmae (a.g.), aerial rhizoids (a.r.), rhizoidal gemmae (r.g.); * = new record; \# = new to Arabian Peninsula; + = present

\begin{tabular}{|c|c|c|c|c|c|c|c|c|c|c|}
\hline \multirow{2}{*}{ Recorded taxa } & \multicolumn{8}{|c|}{ No. of samples collected from each of the 8 sites } & \multicolumn{2}{|c|}{ Total number of: } \\
\hline & 1 & 2 & 3 & 4 & 5 & 6 & 7 & 8 & Sites & Samples \\
\hline $\begin{array}{l}\text { Fissidentaceae: } \\
* 1 \quad \text { Fissidens arnoldii R. Ruthe } \\
\end{array}$ & & & & 2 & & & & & 1 & 2 \\
\hline $\begin{array}{l}\text { Pottiaceae : } \\
\text { \#2 Anoectangium handelii Schiffn. }\end{array}$ & & & & 1 & & & & & 1 & 1 \\
\hline $\begin{array}{l}\text { *3 Crossidium crassinerve (De Not.) } \\
\text { Jur. }\end{array}$ & & & & 2 & & & & $1 \mathrm{f}$ & 2 & 3 \\
\hline *4 Gymnostomum aeruginosum $\mathrm{Sm}$. & & & & 1 & & & & & 1 & 1 \\
\hline *5 G. mosis (Lorentz) Jur. \& Milde & & & & 1a.g. & & & & & 1 & 2 \\
\hline *6 G. viridulum Brid. & & & & 1 & & 1 & & & 2 & 2 \\
\hline 7 Gyroweisia reflexa (Brid.) Schimp. & & & & 1 & & $\begin{array}{l}1 \mathrm{t} \\
2 \mathrm{c}\end{array}$ & & & 2 & 4 \\
\hline $\begin{array}{l}\text { *8 Microbryum davallianum (Sm.) } \\
\text { R.H. Zander }\end{array}$ & & & & $1 \mathrm{f}$ & 1 & $3 \mathrm{f}$ & & $2 f$ & 4 & 7 \\
\hline $\begin{array}{l}\text { \#9. } M \text {. davallianum var. conicum } \\
\text { (Schleich. ex Chwaegr.) R.H. Zander }\end{array}$ & & & & $2 f$ & 1f & $1 \mathrm{f}$ & & & 3 & 4 \\
\hline $\begin{array}{l}\text { \#10. M. davallianum var commutatum } \\
\text { (Limpr.) R.H. Zander }\end{array}$ & & & & & & $1 \mathrm{f}$ & & $1 \mathrm{f}$ & 2 & 2 \\
\hline $\begin{array}{l}\text { *11.M. starckeanum var. starckeanum } \\
\text { (Hedw.) R.H. Zander }\end{array}$ & & $\begin{array}{l}\text { 1f, } \\
\text { a.r. }\end{array}$ & & 1f & $4 \mathrm{f}$ & $6 f$ & 1f & $1 \mathrm{f}$ & 6 & 14 \\
\hline $\begin{array}{l}\text { \#12. M. starckeanum var. brachyodus } \\
\text { (Bruch, Schimp. \& W. Gümbel) R. } \\
\text { H. Zander }\end{array}$ & $\begin{array}{l}1 \mathrm{f}, \\
\text { a.r. }\end{array}$ & & & & 1f & & & & 2 & 2 \\
\hline $\begin{array}{l}\text { *13. Pseudocrossidium prophyroneura } \\
\text { (Müll. Hal. ex Vent.) R.H. Zander }\end{array}$ & & & & 1 & & & & & 1 & 1 \\
\hline 14. Timmiella barbuloides (Brid.) Mönk. & & & & 1 & & & & & 1 & 1 \\
\hline *15 Tortella inclinata (Hedw.) Limpr. & 1a.r. & & & & & & & 2a.r & 2 & 3 \\
\hline *16 Tortula lanceolata R.H. Zamder & & & & & $2 \mathrm{f}$ & & & $1 \mathrm{f}$ & 2 & 3 \\
\hline $\begin{array}{l}\text { *17 Trichostomum } \\
\text { brachydontium Bruch }\end{array}$ & & $\begin{array}{l}\text { 1r.g., } \\
\text { a.r., } \\
\text { c,t }\end{array}$ & & & & & & & 1 & 1 \\
\hline *18 T. crispulum Bruch & & & & & & 1f & & & 1 & 1 \\
\hline *19 Weissa condensa (Voit) Lindb. & & & & 1 & & & $\begin{array}{l}1 \mathrm{f}, \\
\text { a.r }\end{array}$ & & 2 & 2 \\
\hline *20 W. latuiscula Müll. Hal. & $1 \mathrm{c}, \mathrm{t}$ & 1 & & 2 & 1 & 1 & 1 & 1a.r & 7 & 8 \\
\hline \#21 W. rutilans (Hedw.) Lindb. & & & 1 & & & & & & 1 & \\
\hline $\begin{array}{l}\text { Funariaceae: } \\
\text { *22 Entosthodon attenuatus (Dicks.) } \\
\text { Bryhn }\end{array}$ & & & & $2 \mathrm{f}$ & 1f & $6 f$ & 1f & $2 f$ & 5 & 12 \\
\hline *23. Funaria muhlenbergii Turner & & & & 1 & & & & & 1 & 1 \\
\hline *24 F. pulchella H. Philib. & & & & $3 \mathrm{t}$ & $1 \mathrm{t}$ & 2 & & & 3 & 6 \\
\hline $\begin{array}{l}\text { Bryaceae: } \\
\text { *25 Bryum bicolor } \text { Dicks. } \\
\end{array}$ & & & & $\begin{array}{l}2 \mathrm{t}, \\
\text { r.g. }\end{array}$ & $\begin{array}{l}1 \\
\text { r.g }\end{array}$ & 3 & & $\begin{array}{l}1 \\
\text { r.g }\end{array}$ & 4 & 7 \\
\hline $\begin{array}{llll}\# 26 & \text { B. pseudotriquetrum (Hedw.) P. } \\
\text { Gaertn., G. Mey. \& Scherb. } & & \end{array}$ & & & & 1 & & 3 & & 1 & 3 & 5 \\
\hline $\begin{array}{l}\text { Hepaticae : } \\
\text { \#Riccia subbifurca Warnst. ex Croz. }\end{array}$ & & & & + & & & & & & \\
\hline
\end{tabular}

Table 1 shows that the most widespread and most frequent taxa are: Weissia latuiscula (7 sites, 8 samples), Microbryum starckeanum var. starckeanum (6 sites, 14 
samples), Entosthodon attenuatus (5 sites, 12 samples), Bryum bicolor and Microbryum davallianum (4 sites, 7 samples each). The other 21 taxa exist in 1-3 sites and are represented by 1-6 samples each. Weissia rutilans is the only moss recorded in site 3; a site distinct by being exposed to sun almost all day round. This moss has not been recorded in any other site.

Most of the collected taxa seem to be well established in the study area, then 10 taxa carried sporophytes, three taxa had archegoina and antheridia, two taxa had only antheridia, two taxa carried rhizoidal gemmae and one taxon carried axillary gemmae. Five out of the 10 sporulated taxa belong to Microbryum, i.e. all entities of this genus were sporulated. Almost all collected samples of the four genera; Microbryum, Entosthodon, Tortella and Tortula were sporulated.

Six of the recorded taxa (in sites $1,2,7,8$ ) showed the "peculiar phenomenon" referred to only once before in desert mosses from Kuwait by El-Saadawi (1979b). These six taxa were found to have developed among their upper leaves, upward growing, unbranched, straight, rigid, needle-like, deep-red rhizoids.

The 26 recorded mosses belong to four families and 15 genera. The largest family is Pottiaceae (20 taxa), followed by Funariaceae ( 3 taxa), Bryaceae ( 2 taxa) and Fissidentaceae (one taxon). The largest genus is Microbryum (5 entities) followed by Gymnostomum and Weissia (3 entities each) then Trichostomum and Funaria (2 entities each). The other 11 genera are represented by one entity each.

\section{Old and new records}

The two hepatics: Cyathodium africanum Mitt. and Exormotheca pustulosa Mitt., reported earlier (cf. Long, 1987; Frey \& Kürschner, 1988) from montane sites near Masafi and Fujayrah respectively (Fig.2), were not encountered in this work, so also the moss Splachnobryum procerimum Dix. et P.Varde which was reported from montane sites between Dibba and Masafi. These places were not visited for this work (see Fig.2). Other old records made by Frey \& Kürschner (1988) namely: Gyroweisia reflexa and Timmiella barbuloides (both from near Masafi) have been collected in this work.

On the other hand 24 out of the 26 collected mosses represent new records to UAE, six to the Arabian Peninsula and one (Weissia rutilans) to AS5.

The single hepatic Riccia subbifurca recorded in this work is not only a new record to UAE but also to the whole area of the Arabian Peninsula.

\section{Aeronemata}

As to the upward-growing peculiar rhizoids reported here for six taxa and earlier by El-Saadawi (1979b) from Kuwait, in four other taxa; it is plausible to think that they are a means of survival against the probable destructive effect of increased humidity associated with decreased light intensity brought about by comparatively large number of cloudy and rainy days.

Increased humidity associated with low porosity of rocks causes gathering of rain water to be held for some time in relatively sheltered microhabitats (e.g. rock crevices) in amounts sufficient to submerge the tiny mosses dwelling in such niches. This apparently triggers the development of the aerial rhizoids by which means the endangered mosses 
can escape the fate of being soaked in (or submerged under) water for comparatively long periods of time. That these aerial rhizoids readily develop chloronemata that naturally propagate the moss, has been discussed by El- Saadawi (1979b).

Observations common to mosses with aerial rhizoids in Kuwait and in UAE which led to the above understanding are:

1- the aerial rhizoids were reported in the season which witnessed the largest number of cloudy and rainy days. The factor which seems to trigger the development of aerial rhizoids is the rains that are not interrupted by long dry spells (cf. Halwagy \& El-Saadawi, 1992). This was the case in Kuwait in the $1975 / 76$ season which coincided with the largest amount of annual rainfall ever recorded in Kuwait viz. $260.2 \mathrm{~mm}$, compared to $171.2 \mathrm{~mm}$ in $1974 / 75$ and $43.5 \mathrm{~mm}$ in 1976/77 (cf. Halwagy \& El- Saadawi, 1992). In UAE the aerial rhizoids were reported also in the good rainy season of 1997/98. In this season many of the days were cloudy and light or heavy showers fell most of the time. For example during the period of collection from 23 Jan. to 13 Feb. 1998 the amount of rainfall in only one day (the $26^{\text {th }}$ of Jan.) was $17.2 \mathrm{~mm}$ in Fujayrah, $16.3 \mathrm{~mm}$ in Masafi, 9 $\mathrm{mm}$ in Khour-fakan and ranged from 3 to $45.2 \mathrm{~mm}$ in other parts of the Emirates. And the amount of rainfall for the 1997/98 season (October- April) was $149.1 \mathrm{~mm}$ while it was only $40.5 \mathrm{~mm}$ for the same period in 1998/99 (Fujayrah Meteorological Office).

2- The aerial rhizoids are developed by fruiting and nonfruiting mosses growing in relatively sheltered sites and never by mosses growing on exposed rocks (where light is more bright and water cannot be held for long periods).

The strong negative geotropism shown by these aerial rhizoids finds parallel in the vertical upward growth of secondary caulonemata that form when moss gametophores are placed in the dark for several days (cf. Chaban et al. 1998). Therefore, upward growing of aerial rhizoids and secondary caulonemata are survival means developed by mosses endangered by continual increased moisture content or prolonged darkness respectively.

The aerial rhizoids being developed in 10 different mosses ( 8 Pottiaceae, one Bryaceae and one Fissidentaceae) in different parts of the Arabian Peninsula renders it a phenomenon that may warrant calling them "aeronemata".

It has to be said in conclusion that although the present study added a considerable number of new records, yet there is still a good opportunity to have many new records from the vast montane areas that have not been yet visited.

\section{Acknowledgements}

Cordial thanks are due to Eng. Ala'a W. El-Saadawi for inviting the second author to visit UAE from 23 Jan.-13 Feb. 1998, for offering accommodation, transport and guidance to sites of collection. Without his kind help this work would have been impossible. Thanks are also due to Prof. Dr. Nat. Vania of Charles University, for kindly determining the hepatic specimen. 
Contributions to a Bryoflora of the UAE

\section{References}

Al-Gifri, A.N. \& Kürschner H. 1996. First records of bryophytes from the Hadramout and Abyan Governorate, Southern Yemen. Studies in Arabian bryophytes 20. Nova Hedwigia 62: 137-146.

Al-Gifri, A.N., Kürschner, H. \& Mies, B. 1995. New records, additions and a new species, Sematophyllum socotrense Buck (Sematophyllaceae, Musci) to the bryophyte flora of Socotra (Yemen). Studies in Arabian bryophytes 19. Nova Hedwigia 61: 467- 480.

Al-Hasan, R.H., El-Saadawi, W.E., Ali, M.A. \& Radwan, S.S. 1989. Arachidonic and Eicosapentaenoic acids in lipids of Bryum bicolor Dicks. Effects of controlled temperature and illumination. The Bryologist 92(2): 178-182.

Arts, T. 1998. A revision of the moss genus Gymnostomiella Fleisch. Journal of Bryology 20: 411-427.

Balfour, I.B. 1903. The ferns, mosses and liverworts of Sokotra. In: FORBES H. O. (ed): The natural history of Sokotra and Abd-el kuri. London. Pp. 537-541.

Bruggeman-Nannenga, M.A. 1987. An annotated list of Fissidens species from the Yemen Arab Republic and Sultanate of Oman, with F. laxetexturatus nov. spec. Studies in Arabian bryophytes 7. Nova Hedwigia 45: 113- 117.

Chaban, C.I., Kern V.D., Ripetskyj, R.T., Demkiv, O.T. \& Sack, F.D. 1998. Gravitropism in caulonemata of the moss Pottia intermedia. Journal of Bryology 20: 287 299.

Degadillo, C.M. 1982. Pseudoaloina (Pottiaceae, Musci), a new genus from Yemen. The Bryologist 85: 401- 404

El-Saadawi, W.E. 1976. Some mosses from Kuwait. The Bryologist 79: 515-518.

El-Saadawi, W.E. 1978. Observations on drought resistance in some Kuwaiti desert mosses. Proceedings of the Egyptian Academy of Science 31: 265-270.

El-Saadawi, W.E. 1979a. Contribution toward a moss flora of Kuwait. Journal of the University of Kuwait 6: 125- 152.

El-Saadawi, W.E. 1979b. Peculiar aerial rhizoids in some mosses from Kuwait. Journal of Bryology 10: 575.

El-Saadawi, W.E. \& Zanaty, M.S. 1990. Bryum bicolor Dicks and Funaria hygrometrica Hedw. develop remarkable persisting structures in extreme environment. Jounal of Hattori Botanical Laboratory 68: 285-291.

Forsskål, P. 1775. Flora aegyptiaco-arabica. Sive descriptiones plantarum, quas per Aegyptum inferiorem et Arabium felicem detexit, illustravit Petrus Forsskål. Post mortem auctoris edidit Carsten Niehbuhr. Accedit tabula Arabiae felicis geographico- botanica. Copenhagen, cxxvi, $219 \mathrm{p}$.

Frey, W. \& Kürschner, H. 1982. The first records of bryophytes from Saudi Arabia. Studies in Arabian bryophytes 1. Lindbergia 8: 157- 160.

Frey, W. \& Kürschner, H. 1988. Bryophytes of the Arabian Peninsula and Socotra. Floristics, phytogeography and definition of the Xerothermic Pangaean element. Studies in Arabian bryophytes 12. Nova Hedwigia 46: 37- 120

Frey, W. \& Kürschner, H. 1991. Conspectus Bryophytorum Orientalum et Arabicorum. An annotated catalogue of the bryophytes of Southwest Asia. Bryophytorum Bibliotheca 39: 1- 181 . 
Frey, W. \& Kürschner, H. 1993. Targionia hypophylla L. ssp. linealis (Marchantiidae, Hepaticae), eine neue Unterart aus Saudi Arabien sowie weitere Neufunde. Studien an arabischen Bryophyten 17. Nova Hedwigia 57: 127- 133.

Halwagy, M. \& El-Saadawi, W.E. 1992. Drought and changes in the bryoflora and angiosperm flora in Kuwait in the years 1974- 1990. Acta Botanica Neerlandca 41: $183-195$.

Hepper, F.N. 1977. Outline of the vegetation of the Yemen Arabic Republic. Publications from the Cairo University Herbarium 7/8: 307- 322.

Hodgetts, N.G., Matcham, H.W. \& Duckett, J.G. 1999. Bryophytes collected in Lesotho, the Natal Drakensberg and the Orange Free State, Southern Africa. Journal of Bryology 21: 133- 155 .

Kürschner, H. 1996a. Additions to the bryophyte flora of Yemen. New records from the Taizz and Jiblah areas. Studies in Arabian bryophytes 21. Nova Hedwigia 62: 233- 246

Kürschner, H. 1996b. Towards a bryophyte flora of the Near and Middle East ,New records from Iran, Jordan, Kuwait, Lebanon, Oman, Saudi Arabia, Syria and Turkey. Nova Hedwigia 63: 261- 271.

Kürschner, H. 1997. An annotated, corrected, and updated list of the Bryological literature of southwest Asia. Cryptogamie, Bryol. Lichénol.18 (1): 1-46.

Long, D.G. 1987. Hepticae and Anthocerotae of the Arabian Peninsula. Studies in Arabian bryophytes 10. Nova Hedwigia 45: 175- 195

Mitten, W. 1888. Muscineae. In: Balfour J.B.: The botany of Socotra, pp. 330- 336. Transactions of the Royal Society of Edinburgh 31: 1- 446.

Müller, C. 1901. Genera Muscorum fondosorum. Leipzig, 474 S.

Ochi, H. \& Kürschner, H. 1988. Bryum nanoapiculatum (Bryaceae, Musci), a species new to the moss flora of the Arabian Peninsula. Studies in Arabian Bryophytes 13. Nova Hedwigia 47: 359- 361.

Schweinfurth, G. 1884. Ein Besuch auf Socotra mit der Riebeckschen Expedition. Freiburg.

Thériot, I., Dixon, H.N. \& Buch, H. 1934. Bryphyta nova (17-25). Annales Bryologici 7: 157-162.

Townsend, C.C. 1969. Bryophytes from Socotra. Transactions of the British Bryological Society 5: 131- 135.

Townsend, C.C. 1979. A new combination in African Tortula. Journal of Bryology 10: 576.

Whitehouse, H.L.K. \& Crundwell, A.C. 1991. Gymnostomum calcareum Nees \& Hornsch. and allied plants in Europe, North Africa and the Middle East. Journal of Bryology 16: 561- 579.

Whitehouse, H.L.K. \& Crundwell, A.C. 1992. Gymnostomum calcareum Nees \& Hornsch. and G. viridulum Brid. in Europe, North Africa and the Middle East. Bulletin of the British Bryological Society 59: 35- 50

Wijk, R., Margadant, W.D. \& Florschiitz, P.A. 1959-69. Index Muscorum, 1-5, Regnum vegetabile 17,26,33,48 \& 65.

Zander, R.H. 1993. Genera of the Pottiaceae: mosses of Harsh environments. Bulletin of the Buffalo Society of Natural Sciences 32: 1- 378. 